\title{
Feeding habits of the Guiana dolphin, Sotalia guianensis (Cetacea: Delphinidae), in Norte Bay, southern Brazil
}

\author{
FÁBIO G. DAURA-JORGE ${ }^{1,2}$, LEONARDO L. WEDEKIN ${ }^{2,3}$ \\ and PAULO C. SIMÕES-LOPES ${ }^{1}$ \\ ${ }^{1}$ Departamento de Ecologia e Zoologia, Universidade Federal de Santa Catarina, Florianópolis, SC, 88040-900, Brazil. \\ E-mail: daurajorge@yahoo.com.br \\ ${ }^{2}$ Curso de Pós-Graduação em Zoologia, Universidade Federal do Paraná, Curitiba, PR, Brazil. \\ ${ }^{3}$ Instituto Baleia Jubarte, Caravelas, BA, Brazil.
}

\begin{abstract}
SUMMARY: The stomach contents of 18 Guiana dolphins stranded or accidentally caught by fishing around Norte Bay of Santa Catarina Island between 1990 and 2006 were examined. The small population of Guiana dolphins studied showed a varied diet, and prey was caught disproportionately. The stomach contents of these dolphins consisted of 448 prey remains coming from 18 species and 10 families. Their diet primarily consisted of fish, but also shrimp and squid. The most important species were cutlass fish (Trichiurus lepturus) and white mouth croaker (Micropogonias furnieri), which together comprised $75 \%$ of the total biomass. Although prey size ranged widely from 1.4 to $92.8 \mathrm{~cm}$, a prevalence of prey smaller than $20 \mathrm{~cm}$ was observed. There was a predominance of prey living in moderate or large schools. The prey also had a wide vertical distribution in the water column. Our results support the opportunistic feeding habit of the Guiana dolphin, since its diverse diet was clearly guided by the availability and accessibility of resources in its habitat.
\end{abstract}

Keywords: diet, stomach contents, Guiana dolphin, prey availability, southern Brazil.

RESUMEN: Alimentación del delfín costero, Sotalia guianensis (Cetacea: Delphinidae), en la bahía Norte al SUR DE BRASIL. - Se estudiaron los contenidos del estómago de 18 delfines costeros capturados accidentalmente por redes de pesca o encontrados encallados alrededor de la bahía Norte de la isla de Santa Catarina entre 1990 y 2006. La composición de la dieta de los delfines fue variada, pero con predominio de algunas presas. Los contenidos estomacales consistieron en 448 restos de presas, que correspondieron a 18 especies y 10 familias. La mayoría de las presas fueron principalmente peces, pero también estuvieron representados cefalópodos y crustáceos. Las especies más importantes fueron el pez sable (Trichiurus lepturus) y la corvina rubia (Micropogonias furnieri), que juntos representaron un $75 \%$ de la biomasa total. Aunque el tamaño medio de las presas varió entre 1.4 y $92.8 \mathrm{~cm}$, hubo una prevalencia de presas más pequeñas de $20 \mathrm{~cm}$. Se observó un predominio de presas que viven agregadas en cardúmenes de mediano a gran tamaño y con amplia distribución vertical en la columna de agua. Nuestros resultados apoyan el hábito alimenticio oportunista de Sotalia guianensis, ya que su variada dieta está claramente guiada por la disponibilidad y accesibilidad de los recursos en su hábitat.

Palabras clave: dieta, contenidos estomacales, Sotalia guianensis, disponibilidad de presas, sur de Brasil.

\section{INTRODUCTION}

Diet studies of marine predators provide important information on their ecology and ecosystem, as well as on the biology of their prey (Katona and Whitehead, 1988). Some aspects to consider are the identification of key prey and prey availability (Silva, 1999). In general, predator behavior is a response to the distribution and abundance of feeding resources (Krebs, 2001). Food availability is thought to be the most important factor determining spatial patterns, behavior and foraging strategies of Delphinidae (e.g. Wells et al., 1980; Shane, 1990). Thus, knowledge of feeding habits is required to understand the influences of their prey on the ecology of small cetaceans. 
The Guiana dolphin, Sotalia guianensis (P.J van Bénéden, 1864), is widely and continuously distributed along the central and southwestern Atlantic coast (Borobia et al., 1991). The species occurs in bays and estuaries from Honduras (Silva and Best, 1996) to Norte Bay of Santa Catarina Island in southern Brazil (Simões-Lopes, 1988), where a small population (around 60 individuals) shows a high degree of site fidelity (Flores, 1999; Daura-Jorge et al., 2007). Previous studies have described the role played by seasonal variation in the behavior of Guiana dolphins, such as spatial distribution and movements (Daura-Jorge et al., 2005, 2007; Wedekin et al., 2007). The authors proposed that the behavior pattern was strongly driven by seasonal variations in prey abundance. However, the lack of information about the feeding habits of this species in the area make it impossible to test this hypothesis.

Recently, some efforts have been made to describe the diet of the Guiana dolphin along the entire Brazilian coast (e.g. Borobia and Barros, 1989; Santos and Haimovici, 2001; Santos et al., 2002; Gurjão et al., 2003; Di Beneditto and Siciliano, 2007). These studies, despite the small sample size in most cases, revealed that the composition of prey differed between habitats and geographic areas. To provide additional data on the feeding habits of the Guiana dolphin, specifically on the small population from Norte Bay of Santa Catarina Island, we present a qualitative description of their diet. Aware of the limited sample size, we have attempted to make some inferences regarding feeding ecology.

\section{MATERIALS AND METHODS}

\section{Study area}

Norte Bay of Santa Catarina Island (27 $30^{\circ} \mathrm{S}$ and $48^{\circ} 35^{\prime} \mathrm{W}$ ) in southern Brazil (Fig. 1) is a protected coastal bay delimited by a mosaic of rocky shores, sandy beaches and mangroves. Its oceanographic parameters are similar to those of the adjacent open waters (Cerutti, 1996), and it is strongly influenced by tidal and drift currents, as well as by the flow of freshwater (Alongi, 1998). It is also an important nursery habitat for many fish species. The water temperature varies markedly between seasons $\left(15\right.$ to $29^{\circ} \mathrm{C}$; Cerutti, 1996).

\section{Data sample}

The stomach contents of 20 Guiana dolphins found stranded throughout the study area between 1990 and 2006 were examined. The recovered carcasses were measured and sexed during the necropsy (according to Norris, 1961). The stomachs were removed and frozen for subsequent examination. A total of 18 stomachs containing prey remains were analyzed. The other two were not used because one was from a calf, containing only milk, and the other was in an advanced state of decomposition.

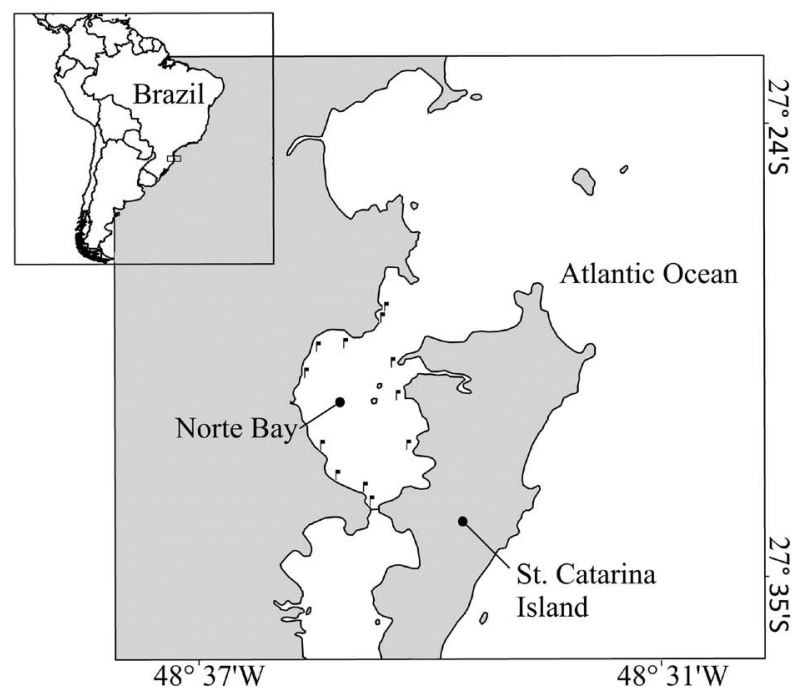

FIG. 1.- Geographic locations of Norte Bay and the stranded Guiana dolphins (flags indicate only the stranded dolphins with exact locations known).

Stomach contents were removed and cleaned with water on a $1 \mathrm{~mm}$ mesh sieve (according to Amir et al., 2005). Intact or partially digested prey were identified, measured and preserved in 70\% alcohol. Remains of hard parts such as fish otoliths, cephalopod beaks and crustacean carapaces were dried at $60^{\circ} \mathrm{C}$ for 48 hours. All prey items were identified to the lowest possible taxonomic level (according to Lêmos et al., 1992; Abilhôa and Corrêa, 1993; Corrêa and Viana, 1993; Lêmos et al., 1995a, b). A fish (and otolith) reference collection assembled by NEMAR (Núcleo de Estudos do Mar - Universidade Federal de Santa Catarina) was also used to help identify prey items. Intact or semi-digested prey were identified according to Figueiredo and Menezes $(1978,1980,2000)$ and Menezes and Figueiredo $(1980,1985)$. The minimum number of prey consumed by each dolphin was estimated by counting the left or right otolith (whichever was more numerous) for fish and lower or upper beaks (whichever was more numerous) for cephalopods. Poorly preserved and/or broken otoliths were discarded to avoid identification mistakes and overestimations, as well as to reduce the risk of secondary contamination (Fitch and Brownell, 1968).

A stereomicroscope with an optical micrometer was used to measure prey items. These measurements were inserted into the linear regression equations (LRE) available in the literature for each identified species (see Corrêa and Viana, 1993; Lêmos et al., 1992, 1995a, b; Di Beneditto et al., 2001), to estimate the size and biomass of each prey specimen.

\section{Data analysis}

The following three parameters were used to calculate the Index of Relative Importance of each prey specimen (IRI; Pinkas et al., 1971): percentage number 
TABLE 1. - Descriptive parameters of prey importance in the diet of the Guiana dolphin from Norte Bay. Abbreviations: Individual number $(\mathrm{N})$, percentage number $(\% \mathrm{~N})$, frequency of occurrence $(\mathrm{FO})$, percentage of frequency of occurrence $(\% \mathrm{FO})$, biomass $(\mathrm{B})$, percentage of biomass (\%B), Index of Relative Importance (IRI), not calculated (-); Prey codes (CD), vertical guilds (VG), ecological guild (EG), size of schools $(S S)$ and habitat type $(H T)$ - see the significance of codes throughout the text.

\begin{tabular}{|c|c|c|c|c|c|c|c|c|c|c|c|}
\hline Prey species & $\mathrm{CD}$ & $\mathrm{N}$ & $\% \mathrm{~N}$ & $\mathrm{~B}(\mathrm{~g})$ & $\% \mathrm{~B}$ & $\% \mathrm{FO}$ & IRI & $V G$ & $E G$ & $S S$ & $H T$ \\
\hline Trichiurus lepturus & $\mathrm{Tl}$ & 30 & 16.8 & 5498 & 51.8 & 61.1 & 4197 & $\mathrm{dp}$ & $\mathrm{mv}$ & ls & ce \\
\hline Micropogonias furnieri & Mf & 48 & 26.9 & 2499 & 23.6 & 66.7 & 3368 & $\mathrm{dn}$ & $\mathrm{mj}$ & ms & ce \\
\hline Cetengraulis edentulus & $\mathrm{Ce}$ & 26 & 14.6 & 485 & 4.6 & 44.4 & 852 & pl & $\mathrm{mv}$ & $\mathrm{ms}$ & ce \\
\hline Mugil cf. curema & $\mathrm{Mc}$ & 16 & 8.9 & 761 & 7.2 & 27.8 & 449 & $\mathrm{pl}$ & $\mathrm{mv}$ & ls & ce \\
\hline Isopisthus parvipinnis & Ip & 9 & 5.0 & 183 & 1.7 & 33.3 & 226 & $\mathrm{dn}$ & $\mathrm{mj}$ & $\mathrm{ms}$ & ce \\
\hline Stellifer cf. rastrifer & $\mathrm{Sr}$ & 10 & 5.6 & 81 & 0.8 & 27.8 & 177 & $\mathrm{dn}$ & $\mathrm{mj}$ & ss & ce \\
\hline Lycengraulis grossidens & $\mathrm{Lg}$ & 10 & 5.6 & 282 & 2.6 & 11.1 & 92 & $\mathrm{pl}$ & rs & $\mathrm{ms}$ & ce \\
\hline Lolliguncula brevis & $\mathrm{Lb}$ & 6 & 3.4 & 67 & 0.6 & 22.2 & 89 & $\mathrm{dp}$ & $\mathrm{mv}$ & st & ce \\
\hline Porichthys porosissimus & $\mathrm{Pp}$ & 3 & 1.7 & 231 & 2.2 & 11.1 & 43 & bt & $\mathrm{mv}$ & ss & ct \\
\hline Pomadasys corvinaeformis & $\mathrm{Pc}$ & 3 & 1.7 & 75 & 0.7 & 16.7 & 40 & $\mathrm{dn}$ & $\mathrm{mj}$ & ls & ce \\
\hline Cynoscion jamaicensis & $\mathrm{Cj}$ & 4 & 2.3 & 73 & 0.7 & 11.1 & 33 & $\mathrm{dn}$ & $\mathrm{mj}$ & ls & ce \\
\hline Orthopristis ruber & $\mathrm{Or}$ & 4 & 2.3 & 210 & 1.9 & 5.6 & 23 & $\mathrm{dn}$ & $\mathrm{mj}$ & ls & co \\
\hline Paralonchurus brasiliensis & $\mathrm{Pb}$ & 4 & 2.3 & 114 & 1.0 & 5.6 & 18 & $\mathrm{dn}$ & $\mathrm{mj}$ & ss & ce \\
\hline Ctenosciaena gracilicirrhus & $\mathrm{Cg}$ & 4 & 2.3 & 26 & 0.2 & 5.6 & 14 & $\mathrm{dn}$ & $\mathrm{mj}$ & SS & ce \\
\hline Chloroscombrus chrysurus & $\mathrm{Cc}$ & 1 & 0.6 & 22 & 0.2 & 5.6 & 4 & $\mathrm{pl}$ & rs & $\mathrm{ms}$ & ce \\
\hline *Citharichthys sp. & $\mathrm{Cs}$ & 200 & - & - & - & 11.1 & - & bt & rs & st & es \\
\hline *Anchoa sp. & Ac & 3 & - & - & - & 16.7 & - & pl & rs & $\mathrm{ms}$ & ce \\
\hline *Penaoidae & $\mathrm{Pe}$ & 1 & - & - & - & 5.6 & - & bt & $\mathrm{mv}$ & st & ce \\
\hline *Unidentified & & 66 & - & - & - & 61.1 & - & & & & \\
\hline Total & & 447 & & 10607 & & & & & & & \\
\hline
\end{tabular}

*Not considered in the IRI analysis

$(\% \mathrm{~N})$, percentage of frequency of occurrence $(\% \mathrm{FO})$ and percentage of biomass $(\% \mathrm{~B})$. This analysis only included species-level identification of those prey with LRE available in order to reduce uncertainty in the analysis.

$$
I R I=(\% N+\% B) \% F O
$$

Despite our small sample size (it is significant considering the population size) we tried to evaluate the degree of feeding specialization using Levins' measure of niche breadth (Krebs, 1998).

Prey species were classified in relation to habits regarding the use of the niche (according to Figueiredo and Menezes, 1978, 1980, 2000; Menezes and Figueiredo, 1980, 1985; Szpilman, 2000), using vertical and ecological guild definitions (adapted from Elliot and Dewailly, 1995). Vertical guilds are related to the depth gradient the prey inhabits and are defined as (bt) benthic (bottom-living), (dn) demersal nektonic (living on the bottom and moving independent of the current), (dp) demersal bentho-pelagic (living on the bottom and up to 200 to $300 \mathrm{~m}$ above) and (pl) pelagic (living mostly off the bottom). The ecological guilds correspond to the degree of residency in protected waters and are classified as (rs) resident (occurring at all seasons and life cycles in estuaries and/or bays), (mv) marine visitors (from coastal and marine habits, occurring occasionally during migratory visits to bays and estuaries) and (mj) marine juvenile (staying in bays and/or estuaries to feed when a juvenile). The term estuary is used here for convenience since Norte Bay is classified as a coastal bay. The size of fish schools, which was also used as a descriptor, was classified into one of the following four categories: (st) solitary, (ss) small school, (ms) moderate school and (ls) large school. Prey were also classified according to their habitat type, including (es) estuarine, (ce) coastal/estuarine, (ct) coastal and (co) coastal/ oceanic (Table 1). Each species was classified as either 0 or 1 (presence/absence matrix) in relation to each descriptor.

\section{Statistical analyses}

A similarity matrix using the Jaccard coefficient was generated for the cluster analysis in which the habits and habitat descriptors of prey were considered. Clusters were determined based on this matrix using the group-average method (UPGMA). The cluster method and the similarity index were chosen considering the highest cophenetic coefficient (Legendre and Legendre, 1998). After clustering, the IRI was recalculated for each formed group. As we considered all prey, the IRI of groups with prey not identified at the species level may be underestimated (biomass not included).

\section{RESULTS}

\section{Sample}

We analyzed the stomachs of eight female and ten male Guiana dolphins. Two females were pregnant with developed embryos, and six animals showed evidence of interactions with fishing activities. Prey items were observed in different degrees of digestion. The average number of prey in each stomach was 25.05 $( \pm 44.8$; range $=1-199)$, and the mean species richness was $3.72( \pm 2.24$; range $=1-8)$. 


\section{Diet composition}

In 18 stomachs we found 448 prey remains and identified $382(85.2 \%)$, including 16 species of fish (from eight different families), one species of squid and one unknown penaeid shrimp. Of the 16 species of fish, two require further confirmation, they are probably Mugil curema (Valenciennes, 1836) and Stellifer rastrifer (Jordan, 1889), and two more were identified at the genus level (Anchoa sp. and Citharichthys sp.). We identified these four prey specimens taking their local habitat and availability into consideration. A sole species of squid, Lolliguncula brevis (de Blainville, 1823), was observed in $22 \%$ of stomachs; it consisted of $1.3 \%$ of the total prey and contributed to $0.6 \%$ of the total estimated biomass. The crustaceans were represented in the diet by one shrimp species (unknown) from the Penaoidae family.

The predominant group was fish, which made up $99.4 \%$ of all evaluated prey. The most frequent family was Sciaenidae (72.2\% of stomachs), followed by Engraulidae (61.1\% of stomachs) and Trichiuridae (61.1\% of stomachs). The highest overall abundance observed was from Paralichthyidae (44.6\% of the prey items), followed by Sciaenidae (17.6\% of the prey items) and then Engraulidae (8.7\% of the prey items). The abundance of Paralichthyidae was due to the occurrence of 195 Citharichthys sp. individuals in one stomach. It was not possible to use the otoliths of Citharichthys sp. and Anchoa sp. to estimate the size and biomass; thus, these prey were not included in subsequent analysis. Due to the exclusion of the above-mentioned species, the Trichiuridae family presented the highest biomass (51.8\%), followed by Sciaenidae $(28.1 \%)$ and then Engraulidae (7.2\%). The family Trichiuridae was represented by one species, Trichiurus lepturus (Linnaeus, 1758), which had an abundance of $16.8 \%$ and a biomass of $51.8 \%$. The family Sciaenidae had the highest species richness $(\mathrm{n}=5)$, with Micropogonias furnieri (Desmarest, 1823) and Isopisthus parvipinnis (Cuvier, 1830) representing 26.9\% and 5.0\% of the total amount of prey and $23.6 \%$ and $1.7 \%$ of the total estimated biomass respectively. Cetengraulis edentulus (Cuvier, 1829), family Engraulidae, was $14.6 \%$ of the abundance and $4.6 \%$ of the total biomass of prey. Mugil cf. curema was also significant, having an abundance of $8.9 \%$ and a biomass of $7.2 \%$ (Table 1).

\section{Relative importance and niche breadth}

The four most important prey species in the diet of the Guiana dolphin, as identified by the Index of Relative Importance (IRI), comprised $67.2 \%$ of the abundance and $87.2 \%$ of the estimated total biomass. These species were Trichiurus lepturus, Micropogonias furnieri, Cetengraulis edentulus and Mugil cf. curema. The first two, T. lepturus and M. furnieri, represented $75.4 \%$ of the total biomass. Biomass was the main factor that contributed to the high IRI of $T$. lepturus, M. furnieri and Mugil cf. curema, whereas abundance increased the IRI of M. furnieri and $C$. edentulus. In relation to families, the highest IRI was observed for Trichiuridae, followed by Sciaenidae and then Engraulidae. It is important to note that almost 195 specimens of Citharichthys sp. occurred in one stomach, which suggests the effect of the small sample size and/or a possible significance of this prey. Levins' measure of niche breadth was 0.51 . This value is exactly between the minimum value (0) and the maximum value (1).

\section{Prey size}

It was possible to observe a wide range of prey sizes $(1.4$ to $92.8 \mathrm{~cm}$ ); however, $77.4 \%$ of all prey were smaller than $20 \mathrm{~cm}$. The average length of prey was $21.4 \mathrm{~cm}( \pm 21.2 \mathrm{~cm})$. The largest and the smallest fish specimens were Trichiurus lepturus $(92.8 \mathrm{~cm})$ and Chloroscombrus chrysurus (Linnaeus, 1766; $1.4 \mathrm{~cm}$ ) respectively. T. lepturus presented the largest average size $(64.0 \pm 17.6 \mathrm{~cm})$, followed by Mugil cf. curema $(18.3 \pm 3.8 \mathrm{~cm})$ and then Porichthys porosissimus $(\mathrm{Cu}-$ vier, 1829) $(17.6 \pm 7.5 \mathrm{~cm})$. Prey weight ranged from $0.8 \mathrm{~g}$ to $511.3 \mathrm{~g}$ and averaged $60.3 \mathrm{~g} \mathrm{(} \pm 95.3 \mathrm{~g})$. However, the majority of prey $(71.9 \%)$ weighed less than 50 g. One Trichiurus lepturus was the heaviest prey recorded $(511.3 \mathrm{~g})$ and this species also showed the largest average weight $(183.3 \pm 129.3 \mathrm{~g})$, followed by P. porosissimus $(76.9 \pm 86.4 \mathrm{~g})$ and then Orthopristis

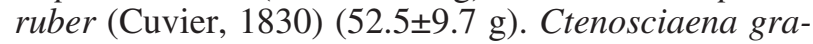
cilicirrhus (Metzelaar, 1919) had the lowest average weight $(6.5 \mathrm{~g})$, and Stellifer cf. rastrifer was the smallest prey specimen $(0.8 \mathrm{~g}$; Table 1$)$.

\section{Prey habits}

Prey species came from estuarine, coastal and oceanic habitats. A wide range of vertical use by the prey was observed, including pelagic, demersal bentho-pelagic and nektonic species. The represented ecological guilds showed a functional diversity of prey; for example, prey included species that were occasional marine visitors to estuaries, migrating species and species that were temporarily visiting as juveniles.

Based on the cluster analysis, at least four groups of prey were observed in relation to these descriptors, and three species formed an "outlier group" (Fig. 2). This outlier group includes species that do not form fish schools, are benthic, inhabit estuaries and are occasional marine visitors. Prey from the second group form small fish schools, are nektonic/demersal, have coastal habitats and use the estuaries and bays as juveniles. The third group is similar to the second group, although prey in the third group form moderate to large schools. The fourth group includes species that form fish schools of moderate to large size, are pelagic and are either estuarine residents or occasional marine visitors. Finally, the fifth group includes prey species that 


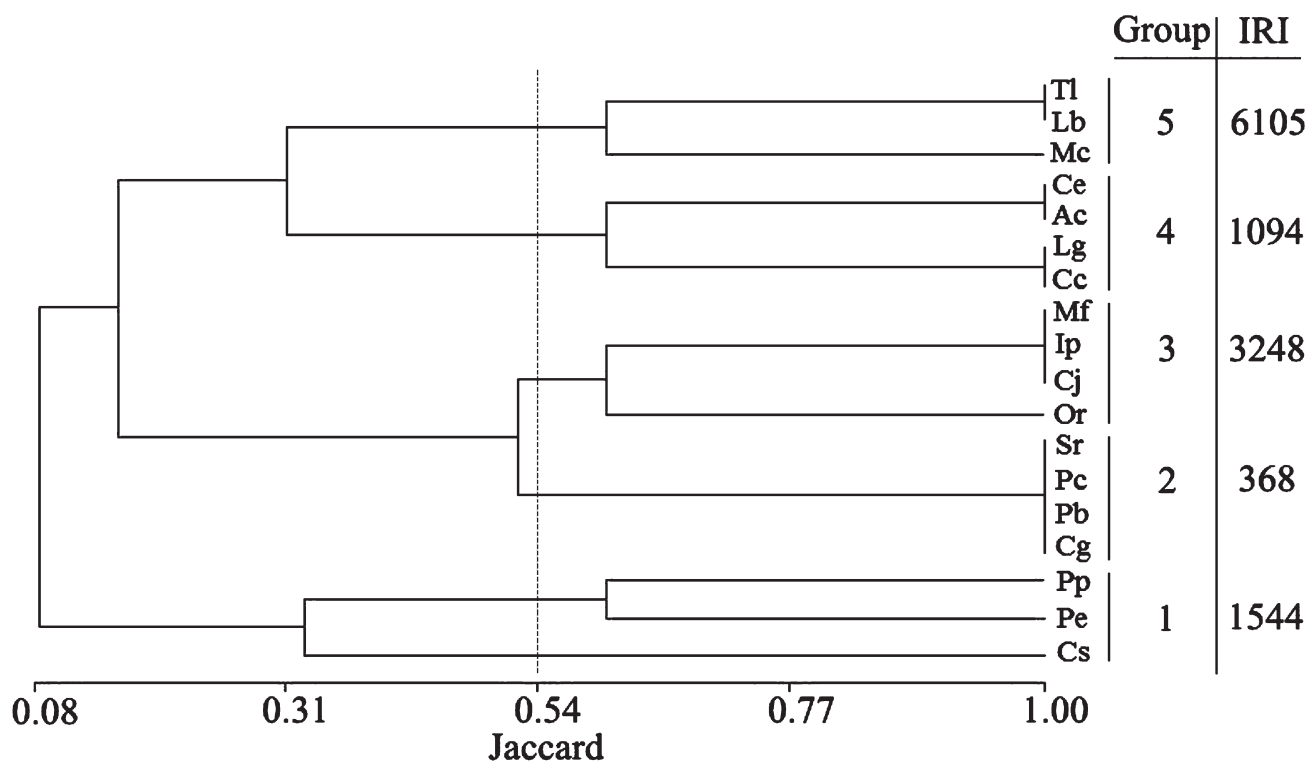

FIG. 2. - Dendrogram of prey species of the Guiana dolphin in Norte Bay in relation to behavior descriptors. Samples were clustered using the Jaccard index. The cophenetic correlation was 0.903 . Abbreviations: Index of Relative Importance (IRI). Prey codes in Table 1 . Each group is described in the text.

form large to moderate schools, are pelagic or benthopelagic and are either occasional marine visitors or visitors during migration periods.

The four most important prey species are in the fifth (Tl and $\mathrm{Mc}$ ), fourth (Ce) and third groups (Mf). Considering only these prey groups, Guiana dolphins mainly eat prey that form moderate to large schools, inhabit estuarine and coastal habitats, have a wide range of vertical distribution and visit the estuary occasionally, either as juveniles or during defined migrations. Nevertheless, the other groups were also well represented in the dolphin's diet. This confirms flexibility and opportunism in the feeding strategies of the Guiana dolphin.

\section{DISCUSSION}

The piscivorous habit observed in Guiana dolphins from Norte Bay has been described in other studies of this species along the Brazilian coast (e.g. Borobia and Barros, 1989; Di Beneditto et al., 2001; Santos et al., 2002; Cremer, 2007; Di Beneditto and Siciliano, 2007), and is common in the diet of small cetacean species (e.g. Young and Cockcroft, 1994; Barros and Wells, 1998; Silva, 1999; Santos and Haimovici, 2001; Amir et al., 2005; De Pierrepont et al., 2005). The cephalopod species Lolliguncula brevis was frequent in the present study, but its contribution in terms of biomass was minimal $(0.7 \%)$. L. brevis is a typical coastal and estuarine species that is cited as a frequent prey of the Guiana dolphin (Santos and Haimovici, 2001); however, this prey species is of small relative importance. Crustaceans are seldom recorded in the diet of the Guiana dolphin. Accordingly, we found only one species of shrimp in the diet of the Norte Bay dolphin population.
Although a diversity of prey was observed in the diet, two species were apparently very important: $T$. lepturus and M. furnieri had the highest IRIs and represented $75 \%$ of the total biomass. Both species were common in other studies on the diet of the Guiana dolphin. T. lepturus was also the most important prey species in the diet of Guiana dolphins from the central and northern coasts of the state of Rio de Janeiro, and $M$. furnieri was among the top five most important prey species along the central coast of the same state (Di Beneditto et al., 2001; Di Beneditto and Siciliano, 2007). C. edentulus and Mugil cf. curema were other important prey species occurring in Norte Bay. $C$. edentulus was the fourth most important prey species for Guiana dolphins from Paranaguá Bay (Zanelatto, 2001). Mugil cf. curema showed little importance in all the areas it was registered (Di Beneditto et al., 2001; Di Beneditto and Siciliano, 2007). Due to the importance of $T$. lepturus, the Trichiuridae family showed the highest IRI, followed by Sciaenidae (with six species) and Engraulidae (with three species). The importance of these families as prey of the Guiana dolphin is supported by the literature. One or more of these species is commonly identified as the most important prey in the diet of the studied populations (e.g. Di Beneditto et al., 2001; Zanelatto, 2001; Oliveira, 2003; Di Beneditto and Siciliano, 2007; Pansard, 2009).

The possibility of a methodological bias that overestimates the importance of these families should be taken into consideration. It is known that Sciaenidae otoliths are larger than the otoliths from other families (Corrêa and Vianna, 1993). This feature could slow down their digestion rate, and therefore increase their chances of being identified and measured. Thus, Sciaenidae's importance for the Guiana dolphin's diet may 
be overestimated (review in Pierce et al., 1991). Similarly, T. lepturus may also be overestimated because of the easy identification of its supraoccipital bone. Finally, a predatory habit of a prey may lead to the overestimation of a prey species. For example, the fact that $T$. lepturus eats sciaenid and engraulid fish (Martins et al., 2005) suggests the possibility of a secondary contamination (Fitch and Brownell, 1968). Independently, the importance of these families in the diet of the population studied here was remarkably high.

Although the size and weight of prey varied, there was a prevalence of prey smaller than $20 \mathrm{~cm}$ and lighter than $50 \mathrm{~g}$. The apparent higher consumption of smaller prey could be due to their high availability; for example, estuaries and coastal bays are generally occupied by marine species at a juvenile stage or by small-sized resident species (Chaves and Bouchereau, 2000). A diversity of prey sizes has been observed in other areas, also with a prevalence of small-sized juvenile prey (Di Beneditto et al., 2001; Santos et al., 2002; Di Beneditto and Siciliano, 2007). T. lepturus was the largest prey observed, probably due to its elongated ribbon-shaped body (Figueiredo and Menezes, 2000). Porichthys porosissimus and Mugil cf. curema had the second largest length and weight respectively. Some of these specimens, and others like M. furnieri and O. ruber, could be considered adults (according to Menezes and Figueiredo, 1980, 1985; Figueiredo and Menezes, 1998), but most were juveniles.

Guiana dolphins most commonly eat species that form moderate to large schools, inhabit estuarine and coastal habitats, and have a wide range of vertical distribution and a functional relationship with the estuary. Nevertheless, analyses of the behavior and habitat of prey suggest that there is some flexibility in the feeding behavior of the Guiana dolphin. The diversity of prey behavior has been reported previously for this species (Di Beneditto et al., 2001; Santos et al., 2002). The importance of prey that form schools, however, has not received much attention in previous studies. Foraging on aggregated prey could be advantageous for dolphins, as it is likely to increase rates of both prey encounter and prey capture. In a study with T. truncatus, Gannon et al. (2005) suggested that passive listening, instead of energetically costly echolocation, could be used to locate prey. This hypothesis explains the high occurrence of noisy prey in the diet of $T$. truncatus (Barros and Wells, 1998), and it may also explain the high occurrence of prey that form moderate to large schools, given the sounds produced by schools.

The prevalence of certain species in the diet was corroborated by a niche breadth analysis that showed an intermediary value. Oliveira (2003) identified a similar result using the same analysis for the Guiana dolphins from Paranaguá/Cananéia. Considering our results, along with existing knowledge of local fish communities, we suggest that the Guiana dolphin population from Norte Bay has a wide diet range although with an apparent opportunistic feeding habit, consum- ing prey with high availability or accessibility in their habitat. Care should be taken when interpreting our results since the large temporal scale suggests a possible change in local communities that may be reflected in diet composition. However, our results still represent an important contribution concerning this small population at the southernmost limit of the species distribution, and are in accordance with other studies on the species. Further study is needed to better understand some diet variations, resource availability dynamics, and the feeding ecology of the Guiana dolphin.

\section{ACKNOWLEDGEMENTS}

This work was supported by the "Fundação de Apoio à Pesquisa Científica e Tecnológica do Estado de Santa Catarina" (FAPESC). The Brazilian Research Bureau (CNPq) funded PCSL (Proc: 304698/2006-7), FGDJ and LLW. We also thank Carlos Espirito-Santo, Gisela Costa Ribeiro and Karim Hahn Lüchmann for their help and suggestions; American Journal Experts and Jeff Stoike for the English version review.

\section{REFERENCES}

Abilhôa, V. and M.F.M. Corrêa - 1993. Catálogo de otólitos de Carangidae (Osteichthyes-Perciformes) do litoral do Estado do Paraná, Brasil. Nerítica, 7: 119-131.

Alongi, D.S. - 1998. Coastal Ecosystem Processes. CRC Press, Florida.

Amir, O.A., P. Berggren, S.G.M. Ndaro and N.S. Jiddawi. - 2005. Feeding ecology of the Indo-Pacific bottlenose dolphin (Tursiops aduncus) incidentally caught in the gillnet fisheries off Zanzibar, Tanzania. Estuar. Coast. Shelf Sci., 63: 429-437.

Barros, N.B. and R.S. Wells. - 1998. Prey and feeding patterns of resident bottlenose dolphins in Sarasota Bay, Florida. J. Mamml., 79: 1045-1059.

Borobia, M. and N.B. Barros. - 1989. Notes on the diet of marine Sotalia fluviatilis. Mar. Mammal Sci., 5: 395-399.

Borobia, M., S. Siciliano, L. Lodi and W. Hoek. - 1991. Distribution of the South American dolphin Sotalia fluviatilis. Can. J. Zool., 69: 1025-1039.

Cerutti, R.L. - 1996. Contribuição ao conhecimento da poluição doméstica na Baía Norte, área da Grande Florianópolis, SC. MSc. thesis. Univ. Santa Catarina.

Chaves, P. and J. Bouchereau. - 2000. Use of mangrove habitat for reproductive activity by the fish assemblage in the Guaratuba Bay, Brazil. Oceanol. Acta, 23: 273-279.

Corrêa, M.F.M. and M.S. Vianna. - 1993. Catálogo de otólitos de Sciaenidae (Osteichthyes-perciformes) do litoral do Estado do Paraná. Nerítica, 7: 13-40.

Cremer, M. - 2007. Ecologia e conservação de populações simpátricas de pequenos cetáceos em ambiente estuarino no sul do Brasil. Ph.D. thesis, Univ. Paraná.

Daura-Jorge, F.G., L.L. Wedekin, V.Q. Piacentini and P.C. SimõesLopes. - 2005. Seasonal and daily patterns of group size, cohesion and activity of the estuarine dolphin, Sotalia guianensis (P.J. van Bénéden) (Cetacea, Delphinidae), in southern Brazil. Rev. Bras. Zool., 22: 1014-1021.

Daura-Jorge, F.G., M.R. Rossi-Santos, L.L. Wedekin and P.C. Simões-Lopes. - 2007. Behavioral patterns and movement intensity of Sotalia guianensis (P.J. van Bénéden) (Cetacea, Delphinidae) in two different areas on the Brazilian coast. Rev. Bras. Zool., 24: 265-270.

De Pierrepont, J.F., B. Dubois, S. Desormonts, M.B. Santos and J.P. Robin. - 2005. Stomach contents of English Channel cetaceans stranded on the coast of Normandy. J. Mar. Biol. Ass. UK, 85: 1539-1546.

Di Beneditto, A.P.M., R.M.A. Ramos and N.R.W. Lima. - 2001. 
Os golfinhos: Origem, classificação, captura acidental e hábito alimentar. Cinco Continentes, Porto Alegre.

Di Beneditto, A.P.M. and S. Siciliano - 2007. Stomach contents of the marine tucuxi dolphin from Rio de Janeiro, southeastern Brazil. J. Mar. Biol. Ass. UK, 87: 253-254.

Elliot, M. and F. Dewailly. - 1995. The structure and components of European estuaries assemblages. Neth. J. Aqua. Ecol., 29: 397-417.

Figueiredo, J.L. and N.A. Menezes. - 1978. Manual de peixes marinhos do sudeste do Brasil. II. Teleostei (1). Museu de Zoologia da Universidade de São Paulo, São Paulo.

Figueiredo, J.L. and N.A. Menezes. - 1980. Manual de peixes marinhos do sudeste do Brasil. III. Teleostei (2). Museu de Zoologia da Universidade de São Paulo, São Paulo.

Figueiredo, J.L. and N.A. Menezes. - 2000. Manual de peixes marinhos do sudeste do Brasil. VI. Teleostei (5). Museu de Zoologia da Universidade de São Paulo, São Paulo.

Fitch, J.E. and R.L. Brownell. - 1968. Fish otoliths in Cetacean stomachs and their importance in interpreting feeding habits. $J$. Fish. R. Boar. Can., 25: 2561-2574.

Flores, P.A.C. - 1999. Preliminary results of a photo identification study of the marine tucuxi, Sotalia fluviatilis, in southern Brazil. Mar. Mammal Sci., 15: 840-847.

Gannon, D.P., N.B. Barros, D.P. Nowacek, A.J. Read, D.M. Waples and R.S. Wells. -2005 . Prey detection by bottlenose dolphins, Tursiops truncatus: an experimental test of the passive listening hypothesis. Anim. Behav., 69: 709-720.

Gurjão, L.M., M.A.A. Furtado-Neto, R.A. Santos and P. Cascon. - 2003. Feeding habits of marine tucuxi, Sotalia fluviatilis, at Ceará State, Northeastern Brazil. Lat. Am. J. Aqua. Mamm., 2: 117-122.

Katona, S. and H. Whitehead. - 1988. Are Cetacea ecologically important? Oceanogr. Mar. Biol., 26: 553-568.

Krebs, C.J. - 1998. Ecological Methodology. Benjamin Cummings, San Francisco.

Krebs, C.J. - 2001. Ecology: The experimental analysis of distribution and abundance. Benjamin Cummings, San Francisco.

Legendre, P. and L. Legendre. - 1998. Numerical Ecology. Elsevier Science, Amsterdam.

Lêmos, P.H.B., M.F.M. Corrêa and V. Abilhôa. - 1992. Catálogo de otólitos de Gerreidae (Osteichthyes-Perciformes) do litoral do Estado do Paraná, Brasil. Nerítica, 7: 109-117.

Lêmos, P.H.B., M.F.M. Corrêa, and P.C. Pinheiro. - 1995a. Catálogo de otólitos de Engraulidae (Clupeiformes-Perciformes) do litoral do Estado do Paraná, Brasil. Braz. Arch. Biol. Techn., 38: 731-745

Lêmos, P.H.B., M.F.M. Corrêa and P.C. Pinheiro. - 1995b. Catálogo de otólitos de Clupeidae (Clupeiformes-Perciformes) do litoral do Estado do Paraná, Brasil. Braz. Arch. Biol. Techn. 38: 747-759.

Martins, A., M. Haimovici, and R. Palacios. - 2005. Diet and feeding of the cutlassfish Trichiurus lepturus in the Subtropical Convergence Ecosystem of southern Brazil. J. Mar. Biol. Ass. $U K, 85: 1223-1229$.

Menezes, N.A. and J.L. Figueiredo. - 1980. Manual de peixes marinhos do sudeste do Brasil. IV. Teleostei (3). Museu de Zoologia da Universidade de São Paulo, São Paulo.

Menezes, N.A. and J.L. Figueiredo. - 1985. Manual de peixes marinhos do sudeste do Brasil. V. Teleostei (4). Museu de Zoologia da Universidade de São Paulo, São Paulo.

Norris, K.S. - 1961. Standardized methods for measuring and recording data on the smaller cetaceans. J. Mammal., 42: 471-476.

Oliveira, M.R. - 2003. Ecologia alimentar de Sotalia guianensis e Pontoporia blainvillei (Cetacea, Delphinidae e Pontoporidae) no litoral sul do Estado de São Paulo e litoral do Estado do Paraná. MSc. thesis, Univ. Paraná.

Pansard, K.C.A. - 2009. Ecologia alimentar do boto-cinza, Sotalia guianensis (Van Benédén, 1864), no litoral do Rio Grande do Norte $(R N)$. MSc. thesis, Univ. Rio Grande do Norte.

Pierce, G.J., P.R. Boyle and J.S.W. Diack. - 1991. Identification of fish otoliths and bones in faeces and digestive tracts of seals. $J$. Zool., 224: 320-328.

Pinkas, L., M.S. Oliphant and I.L.K. Iverson. - 1971. Food habits of albacore, bluefin tuna and bonito in California waters. Calif. Fish. Game, 152: 1-105.

Santos, R.A. and M. Haimovici. - 2001. Cephalopods in the diet of marine mammals stranded or incidentally caught along southeastern and southern Brazil (21-34'). Fish. Res., 52: 99-112.

Santos, M.C.O., S. Rosso, R.A. Santos, S.H.B. Lucato and M. Bassoi. - 2002. Insights on small cetacean feeding habits in southeastern Brazil. Aquat. Mamm., 28: 38-45.

Shane, S.H. - 1990. Behavior and ecology of the bottlenose dolphins at Sanibel Island, Florida. In: S. Leatherwood and R.R. Reeves (eds.), The Bottlenose Dolphin, pp. 245-265. Academic Press, San Diego.

Silva, V.M.E. and R.C. Best. - 1996. Sotalia fluviatilis. Mamm. Spec., 527: 1-7.

Silva, M.A. - 1999. Diet of common dolphins, Delphinus delphis, off the Portuguese continental coast. J. Mar. Biol. Ass. UK, 79: 531-540.

Simões-Lopes, P.C. - 1988. Ocorrência de uma população de Sotalia fluviatilis, Gervais, 1853, (Cetacea, Delphinidae) no limite sul de sua distribuição, Santa Catarina, Brasil. Biotemas, 1: 57-62.

Szpilman, M. - 2000. Peixes Marinhos do Brasil: Guia prático de identificação. Instituto Ecológico Aqualung and MAUAD Editora, Rio de Janeiro.

Wedekin, L.L., F.G. Daura-Jorge, V.Q. Piacentini and P.C. SimõesLopes. - 2007. Seasonal variation in spatial usage by the estuarine dolphin, Sotalia guianensis (van Bénéden) (Cetacea: Delphinidae), at its southern limit of distribution. Braz. J. Biol., 67: 1-8.

Wells, R.S., A.B. Irvine and M.D. Scott. - 1980. The social ecology of inshore odontocetes. In: L.M. Herman (ed.), Cetacean behavior, mechanisms and functions, pp. 263-317. John Wiley, New York.

Young, D.D. and V.G. Cockcroft. - 1994. Diet of common dolphins off the south-east coast of southern Africa: opportunism or specialization? J. Zool., 234: 41-53.

Zanelatto, R.C. - 2001. Dieta do boto-cinza, Sotalia fluviatilis (Cetacea, Delphinidae) no complexo estuarino da Baía de Paranaguá e sua relação com a ictiofauna estuarina. MSc. Thesis, Univ. Paraná.

Scient. ed.: M.P. Olivar.

Received January 8, 2010. Accepted June 8, 2010.

Published online January 10, 2011 